\title{
Inheritance of Tomato yellow leaf curl virus Resistance Derived from Solanum pimpinellifolium UPV16991
}

Ana Pérez de Castro, María José Díez, and Fernando Nuez, Instituto de Conservación y Mejora de la Agrodiversidad, Universidad Politécnica de Valencia, Camino de Vera s/n, 46022 Valencia, Spain

\begin{abstract}
Pérez de Castro, A., Díez, M. J., and Nuez, F. 2007. Inheritance of Tomato yellow leaf curl virus resistance derived from Solanum pimpinellifolium UPV16991. Plant Dis. 91:879-885.

Resistance to tomato yellow leaf curl disease (TYLCD) in accession UPV16991 Solanum pimpinellifolium has been previously reported by our group. A breeding program was developed from an initial $S$. lycopersicum $\times$ S. pimpinellifolium UPV16991 cross. This first cross was followed by several selfing generations. Selection for resistance to Tomato yellow leaf curl virus (TYLCV) and Tomato yellow leaf curl Sardinia virus (TYLCSV) was carried out for plants of each generation. One partially resistant $F_{6}$ plant (L102) was chosen to form the family to study the genetic control of resistance to TYLCV. Crosses between four breeding lines susceptible to TYLCD and L102 were also performed to study the dominance of the resistance in S. lycopersicum genetic backgrounds. Response to TYLCV infection of $\mathrm{P}_{1}, \mathrm{P}_{2}, \mathrm{~F}_{1}, \mathrm{~F}_{2}, \mathrm{BC}_{1}$, and $\mathrm{BC}_{2}$ generations fitted, for this line, a monogenic control with partial recessiveness and incomplete penetrance. The percentage of homozygotic plants with partial resistance was 72.75. Among the four hybrids developed, the highest levels of resistance were found in the hybrid formed from the most vigorous $S$. lycopersicum line. These results must be considered for breeding purposes. Partial resistance derived from UPV16991 will be useful in homozygosis or combined with resistance genes from other sources.
\end{abstract}

Tomato yellow leaf curl disease (TYLCD) causes great losses in tomato (Solanum lycopersicum L.) crops worldwide $(24,27)$. Nine viral species have been reported as causal agents of this disease and five more are considered as tentative species (5). All of them belong to the genus Begomovirus (family Geminiviridae). One of these, Tomato yellow leaf curl virus (TYLCV), has been reported affecting tomato worldwide. In some geographical areas, this species is present in mixed epidemics $(1,22,26)$.

Cultural practices to control the disease rely on management of the insect vector, Bemisia tabaci Genn. Measures such as the use of UV-absorbing high-density mesh can reduce infection levels $(2,34)$. However, these methods are only effective if combined within an integrated management strategy (14,33). Consequently, breeding for resistance to TYLCD is the most advantageous approach to control the damage caused by this viral disease.

Cultivated tomato shows susceptibility to this disease, but variable levels of resistance have been found in numerous accessions of wild-tomato relatives such as $S$.

Corresponding author: Fernando Nuez Viñals E-mail: fnuez@btc.upv.es

Accepted for publication 1 February 2007.

doi:10.1094/PDIS-91-7-0879

(C) 2007 The American Phytopathological Society peruvianum L., S. chilense (Dunal) Reiche, S. habrochaites S. Knapp \& D.M. Spooner, and $S$. pimpinellifolium L. $(17,20,27,28)$. Several of these resistant sources have been employed to develop resistant advanced breeding lines and commercial hybrids $(6,18,28,36,37)$. However, in most cases, resistance sources have been underexploited because of the complex genetics of the resistance (19).

Genetic control of resistance to TYLCD has been studied in accessions of different wild-tomato relatives. Results found in $S$. peruvianum accessions suggest that resistance is conferred by several genetic factors $(19,31,36)$. Resistance derived from $S$. habrochaites LA386 is dominant and controlled by more than one gene (12). Vidavsky and Czosnek (35) derived resistant and tolerant lines from an initial cross between resistant $S$. habrochaites LA1777 and LA386 and concluded that tolerance from these sources was conferred by a dominant major gene while resistance was controlled by two to three additive resistance genes. Resistance found in other sources from this species seems to be controlled by two genes acting epistatically (10). On the contrary, resistance derived from S. chilense LA1969 has been reported to be conferred by one major gene, Ty-1, with two minor modifier genes (37).

$S$. pimpinellifolium results regarding genetic control of the resistance to TYLCV are sometimes contradictory. Pilowsky and Cohen (30) concluded that resistance derived from LA121 was monogenic with incomplete dominance. Subsequent studies developed by Hassan et al. (13) with LA121 suggested that resistance was quantitatively inherited with partially recessive gene action and incomplete penetrance. These authors concluded that inheritance of the resistance found in S. pimpinellifolium LA373 followed this same model. The authors attributed discrepancies to differences in viral species or isolates, environmental conditions or inoculation, and evaluation procedures. Other $S$. pimpinellifolium accessions have also been investigated. Kasrawi (15) concluded that resistance found in accessions HirsuteINRA and LA1478 was controlled by a single dominant gene; the proposed name was Tylc. Vidavsky et al. (36) agreed later with these results for Hirsute-INRA. However, segregation analysis developed by Chagué et al. (3) showed that resistance was inherited following a quantitative pattern. Studies developed with lines derived from different resistant sources of $S$. pimpinellifolium revealed that the gene action for TYLCD resistance varied with the source and was a quantitative trait with some dominance (16). Similar results were found when evaluating $S$. pimpinellifolium accessions PI407543, PI407544, and PI407555 (11). Three pairs of genes were estimated to be controlling the resistance, with complete dominance in PI407543 and PI407544 and partial dominance in PI407555. Gene action was additive in PI407543, while dominance and nonallelic interactions were important in accessions PI407544 and PI407555.

$S$. chilense and $S$. peruvianum are the wild species mainly used to develop hybrids or cultivars resistant to TYLCD. Commercial materials with resistance derived from $S$. pimpinellifolium are not available. In any case, the materials developed from different sources are not immune to TYLCD. Consequently, the efforts of different research groups are still aimed at controlling this disease. One possible way of developing a more durable resistance and increasing its level could be the accumulation of resistance genes from different sources. The study of progenies obtained from interspecific crosses involving S. pimpinellifolium, S. peruvianum, and $S$. habrochaites revealed that they showed higher levels of resistance than either parent (16). Similar results were found with crosses from $S$. peruvianum, $S$. pimpinellifolium, and $S$. chilense, suggest- 
ing that the highest levels of resistance could be obtained combining partly dominant genes from $S$. pimpinellifolium and $S$. chilense (36). More recently, high levels of resistance were also obtained in hybrids that combined resistance from $S$. habrochaites and $S$. pimpinellifolium with $S$. peruvianum-derived resistance (23).

Consequently, it is of interest to exploit resistance derived from $S$. pimpinellifolium, if not on its own, then combined with resistance derived from other wildtomato relatives.

This study was conducted to characterize the resistance to TYLCV derived from S. pimpinellifolium UPV16991, determine the genetic basis of resistance, and study the dominance of this resistance in different S. lycopersicum backgrounds.

\section{MATERIALS AND METHODS}

Plant material. Partial resistance to Tomato yellow leaf curl Sardinia virus (TYLCSV) was detected by our group in S. pimpinellifolium accession UPV16991 (29). A breeding program was initiated to introgress resistance found in this accession into cultivated species. The program was developed from an initial cross between the susceptible $S$. lycopersicum NE1, a breeding line developed at the Institute for the Conservation and Improvement of Agrodiversity (COMAV, Spain), and $S$. pimpinellifolium UPV16991. The first cross was followed by several selfing generations. Selection for resistance to TYLCV and TYLCSV was carried out for plants at each generation. In the $\mathrm{F}_{6}$ generation, one plant of line L102 was selected to form the family in which to study the genetic control of resistance derived from UPV16991. The old Fortuna C cultivar (FC), used as a female parent $\left(\mathrm{P}_{1}\right)$, is highly susceptible to TYLCD and was crossed to $\mathrm{L} 102\left(\mathrm{P}_{2}\right)$. The $\mathrm{F}_{1}$ generation was selfed to provide an $\mathrm{F}_{2}$ generation and also backcrossed as male parent to $\mathrm{FC}$ and L102 to produce the backcross generations $\mathrm{BC}_{1}$ and $\mathrm{BC}_{2}$, respectively. L102 was additionally crossed as male parent to three other susceptible breeding lines developed at the COMAV (NE-1, P-73, and V-5-7). The Pimhir population with partial resistance to TYLCV, developed by Laterrot (21) from $S$. pimpinellifolium HirsuteINRA, was used as the resistant control.

In this study, 20 plants of each parent, of each of the four $F_{1}$ generations developed, as well as those of Pimhir, 150 plants of the $F_{2}$ generation, and 100 plants of each of the backcrosses were tested for their resistance to TYLCV.

Inoculation techniques. Inoculation was carried out with TYLCV. The Spanish TYLCV isolate TYLCV-Mld[ES7297] (GenBank Accession No. AF071228) was maintained in FC tomato plants by whitefly transmission inside muslin-covered cages in a growth chamber. The environmental conditions were: temperature at $25^{\circ} \mathrm{C}$; 60 to $65 \%$ and 95 to $99 \%$ relative humidity (day/night); $34 \mu \mathrm{E} \cdot \mathrm{m}^{-2} \cdot \mathrm{s}^{-1}$ of irradiance; and a 16/8 (light/dark) photoperiod. The whiteflies used were biotype Q (supplied by F. Beitia, Instituto Valenciano de Investigaciones Agrarias, IVIA, Valencia, Spain). Plants to be inoculated were grown in pots in a greenhouse with controlled light and temperature. Plants (the number of plants for each generation is specified in the plant material section) were caged with at least 20 whiteflies per plant at the three true-leaf stage for 3 days. Plants were shaken daily to ensure that the distribution of the whiteflies was uniform. After the inoculation period, plants were sprayed with insecticide (piroproxifen [10\%], bifentrin [10\%], imidacloprid [20\%], teflubenzuron [15\%], and endosulfan [35\%], percentage of each component referred to the total volume of the mixture) and transferred to a new insect-proof cage for 2 days to avoid the spreading of whiteflies. Subsequently, plants were sprayed again with the insecticide, transplanted to bigger pots, and transferred to the greenhouse.

Experimental design. Plants for inoculation were divided among 18 trays. In each of the trays, plants belonging to each of the generations were included. The number of plants of each generation per tray was proportional to total number of plants used in the generation. Plants were distributed randomly in each tray. After inoculation, plants were transplanted to bigger pots in two adjacent greenhouses to the end of the assay. Each greenhouse was in turn divided into two plots. Plants of each generation were distributed in blocks of five plants and distributed randomly in the different plots, again maintaining the proportion of sample size of the generation in each block. Conditions in the greenhouses were: temperatures at 25 to $18^{\circ} \mathrm{C}$ (day/night); $80 \%$ relative humidity; and a 16/8 (light/dark) photoperiod.

Disease assessment. Symptom severity and viral DNA presence were assessed to evaluate the response of each plant at 15 , 25,35 , and 45 days postinoculation (dpi). Additionally, a final evaluation of symptom scores was done at $60 \mathrm{dpi}$ for the six generations used to study the genetic control of resistance.

At each date, the presence of the following symptoms was recorded: yellowing; crumpling; upward curling; reduction in leaf size; and stunting. Additionally, symptom severity was graded according to a scale described by Friedmann et al. (6): 0 $=$ no visible symptoms, inoculated plants show same growth and development as uninoculated plants; 1 = very slight yellowing of leaflet margins on apical leaf; 2 $=$ some yellowing and minor curling of leaflet ends; 3 = a wide range of leaf yellowing, curling and cupping, with some reduction in size, yet plants continue to develop; and $4=$ very severe plant stunting and yellowing and pronounced cupping and curling, plants cease to grow. Intermediate scores $(0.5,1.5,2.5$, and 3.5) were also used to obtain accurate evaluations of symptom severity.

The presence of TYLCV viral DNA was assessed by molecular hybridization. Approximately $150 \mathrm{mg}$ of tissue from the upper canopy of the plant were taken at each date and DNA was extracted following the procedure described by Crespi et al. (4) with some modifications. The frozen tissue was crushed in $500 \mu \mathrm{L}$ of extraction buffer (100 mM Tris-HCl [pH 8], 50 mM EDTA, $500 \mathrm{mM} \mathrm{NaCl}, 10 \mathrm{mM} 2-\beta-$ mercaptoethanol, and $1 \%$ sodium dodecyl sulfate) and incubated at $65^{\circ} \mathrm{C}$ for $5 \mathrm{~min}$. Afterward, $150 \mu \mathrm{l}$ of $5 \mathrm{M}$ potassium acetate were added. Following incubation on ice for $10 \mathrm{~min}$, samples were centrifuged $(16,110 \times g$ for $10 \mathrm{~min})$. The supernatant was recovered and DNA was precipitated with isopropanol by centrifugation $(16,110$ $\times g$ for $5 \mathrm{~min}$ ) and then the DNA was resuspended in $77 \mu \mathrm{l}$ of distilled water. One microliter of each sample, corresponding to approximately $1.5 \mathrm{mg}$ of fresh tissue, and a 10 -fold dilution of the sample were denatured with $30 \mathrm{mM} \mathrm{NaOH}$ and $1 \mathrm{mM}$ EDTA for $30 \mathrm{~min}$ and then blotted onto positively charged nylon membranes for hybridization. DNA was fixed on the membrane by UV crosslinking. Hybridization was carried out according to "The DIG system user's guide for filter hybridization" (Roche Molecular Biochemicals, Mannheim, Germany) using digoxigenin11-dUTP and chemiluminescent detection. Membranes were prehybridized in standard hybridization buffer plus 50\% deionized formamide for at least $1 \mathrm{~h}$. Subsequent hybridization was done at $42^{\circ} \mathrm{C}$ overnight in fresh prehybridization solution containing $20 \mathrm{ng}$ of denatured probe per milliliter. The probe employed (supplied by E. R. Bejarano, Universidad de Málaga, Spain) represented the intergenic region of the Spanish TYLCV isolate previously cited. The probe was labeled by incorporation of digoxigenin-11-dUTP during polymerase chain reaction (PCR). Washing steps and incubation with antibody were done according to the manufacturer's instructions. Detection was carried out with CSPD and direct exposure to a CCD camera (Intelligent Dark Box-II; Fujifilm, Tokyo, Japan).

The amount of viral ssDNA was quantified according to a standard curve of TYLCV dotted on the same membrane (ranging from $25 \mathrm{ng}$ to $1 \mathrm{pg}$ ).

Extracted plant DNA was also quantified to relate virus concentration to plant DNA present in each sample. Fluorimetry was employed as the method of quantifying doubled-stranded DNA (Hoefer DyNA Quant 200 fluorimeter, according to manufacturer's instructions, San Francisco, CA).

Those plants in which viral accumulation was not detected at any sampling date 
were considered to have escaped infection, and were therefore, discarded and not included in the analysis. Plants that became infected by other viral diseases were also eliminated from the assay.

Evaluation criteria. To classify individual plants as partially resistant or susceptible, the limit was established at symptom score 2: plants that scored under 2 were considered partially resistant while plants that scored 2 or higher were considered susceptible. These criteria were set based on the scale described to evaluate symptom development. Slight symptoms $(<2)$ do not affect a plant enough to cause yield losses, and it can therefore, be classified as partially resistant.

Genetic analyses. The observed percentages of partially resistant and susceptible plants at $60 \mathrm{dpi}$ for each generation were fitted to a model appropriate for describing the response observed in the different generations. Parameters of the model were estimated by the least square regression method, considering as weights the number of plants at each generation. The joint fit of all generations to the proposed model was evaluated by the $\chi^{2}$ weighted statistic obtained by the expression: $\chi^{2}$ weighted $=\Sigma[$ (observed relative frequency-expected relative frequency $)^{2} \times$ weight].

\section{RESULTS}

Characterization of the resistance to TYLCD derived from $S$. pimpinellifolium UPV16991. Accession UPV16991 was previously selected from $40 \mathrm{~S}$. pimpinellifolium accessions by our group (29) because it displayed a good response against TYLCD. UPV16991 showed a low percentage of infection, accumulated significantly lower viral amounts than what were found in susceptible genotypes, and exhibited mild symptoms. In the first screening, some plants of the accession were completely symptomless and virusfree when analyzed by squash-blot hybridization, and therefore, were selected to initiate the breeding program. Following a cross with the cultivated species, five selfing generations were developed in which selection for resistance to TYLCSV and TYLCV was carried out. In each genera- tion, the same variation seen in the original source was found. Most of the plants remained symptomless or exhibited mild symptoms, whereas a variable percentage of the plants ( 7 to $30 \%$ ) continued showing susceptibility to the disease with medium to severe symptoms (data not shown). Regarding viral accumulation, it was always lower than the accumulation in the susceptible controls. This response to infection observed in the successive selfing generations was homogeneous, indicating that the gene or genes controlling resistance were fixed.

Thus, assuming that resistance was fixed, one partially resistant $\mathrm{F}_{6}$ plant was selected to form the family to study the genetic control and the dominance in different $S$. lycopersicum genetic backgrounds of the resistance derived from $S$. pimpinellifolium UPV16991. Response to infection in the selected line, L102, was compared with that of the susceptible and resistant controls, FC and Pimhir, respectively. A high percentage of plants of the susceptible FC control showed severe symptoms at 15 dpi (Table 1). At this time, symptoms consisted of yellowing, upward curling, and reduction in leaf size. The disease progressed rapidly and $100 \%$ of susceptible plants ceased to grow at $25 \mathrm{dpi}$. The first severe symptoms (symptom score of $\geq 2$ ) appeared at $25 \mathrm{dpi}$ in the resistance source, L102. Furthermore, some plants recovered, and at $45 \mathrm{dpi}, 86.7 \%$ of the plants showed only slight symptoms and were considered partially resistant. Moreover, the susceptible plants of this generation in no case scored more than 2.5. Symptom appearance was also delayed in plants of the resistant Pimhir control, but at the end of the assay, $47.1 \%$ of the plants were classified as susceptible.

Viral accumulation in L102 and Pimhir was lower than in the susceptible control for all sampling dates. Accumulation peaked for all genotypes at $35 \mathrm{dpi}$ and so this was the most appropriate date to discriminate responses. At this date, viral accumulation detected in Pimhir and in L102 did not differ significantly (Fig. 1).

Resistance was thus expressed in L102 as a delay in time and a recovery of symptom development as well as a lower per-

Table 1. Percentage of partially resistant tomato plants for L102, the controls, and hybrids at different days postinoculation (dpi) with Tomato yellow leaf curl virus ${ }^{\mathrm{a}}$

\begin{tabular}{lrrcc}
\hline Genotype & 15 dpi & 25 dpi & 35 dpi & 45 dpi \\
\hline Fortuna C b $_{\text {L102 }}$ & 10.5 & 0.0 & 0.0 & 0.0 \\
Pimhir & 100.0 & 60.0 & 66.7 & 86.7 \\
V-5-7 $\times$ L102 & 94.1 & 100.0 & 52.9 & 52.9 \\
NE-1 × L102 & 76.5 & 70.6 & 47.1 & 47.1 \\
FC $\times$ L102 & 85.0 & 40.0 & 25.0 & 10.0 \\
P-73 $\times$ L102 & 83.3 & 72.2 & 50.0 & 22.2 \\
\hline
\end{tabular}

${ }^{a}$ A plant was considered partially resistant if the symptom score was less than 2 in a scale from 0 (symptomless) to 4 (severe symptoms).

${ }^{\mathrm{b}}$ Susceptible control.

${ }^{\mathrm{c}}$ Resistant control. centage of plants showing severe symptoms at the end of the assay. Additionally, viral accumulation was always significantly lower than in susceptible controls. The appearance of susceptible plants in L102 (corresponding to the response observed in the previous generations studied) supports that the gene or genes controlling the resistance must have incomplete penetrance.

Inheritance of the resistance to TYLCD derived from $S$. pimpinellifolium UPV16991. Six generations $\left(\mathrm{P}_{1}, \mathrm{P}_{2}\right.$, $\mathrm{F}_{1}, \mathrm{~F}_{2}, \mathrm{BC}_{1}$, and $\mathrm{BC}_{2}$ ) were used to study the genetic control of the resistance in L102. Plants of the susceptible FC parent began showing symptoms of the disease at $15 \mathrm{dpi}$, and as of $25 \mathrm{dpi}$, all plants showed severe symptoms (Table 2). As previously described, the partially resistant L102 parent did not show complete resistance, given that as of 25 dpi some of the plants scored 2 or higher and so were classified as susceptible. However, some of the plants recovered. The partially resistant plants of L102 displayed variable levels of symptoms. The mean symptom score of the $\mathrm{F}_{1}$ generation was lower than the midparent value for all the sampling dates. Even though $77.8 \%$ of the plants were susceptible at $60 \mathrm{dpi}$, none of them showed symptoms that scored over 2.5 (Fig. 2). The $\mathrm{F}_{2}$ generation segregated continuously, and at $60 \mathrm{dpi}$, it was skewed toward susceptibility. The $\mathrm{BC}_{1}$ generation mean was between the $F_{1}$ and $P_{1}$ means throughout the assay. All plants of this generation showed symptoms that scored over 2 at the end of the assay, so resistance was not detected in this generation at $60 \mathrm{dpi}$. The $\mathrm{BC}_{2}$ generation mean was between the $\mathrm{P}_{2}$ and $F_{1}$ means for all sampling dates. Some plants of this generation also recovered from severe symptoms. This generation was very similar to the partially resistant parent, although the percentage of susceptible plants was higher in the $\mathrm{BC}_{2}$. With regard to the maximum symptom score, in none of these generations was it over 2.5 at 60 dpi.

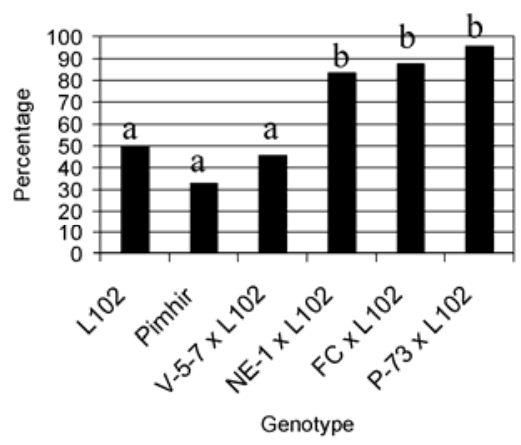

Fig. 1. Viral accumulation of Tomato yellow leaf curl virus at 35 days postinoculation expressed as percentage of susceptible control Fortuna C. Different letters denote statistical differences (LSD multiple range test at the 0.05 protection level). 
Viral accumulation was also measured in individual plants at $15,25,35$, and 45 dpi. The amount of virus detected peaked at $35 \mathrm{dpi}$. The maximum and minimum accumulation levels were found, respectively, in FC and L102. For the rest of the generations, viral accumulation was intermediate, following a similar pattern with respect to symptom development. There was a low positive correlation, though highly significant, between symptom development and viral accumulation ( $r=$ $0.127, P=2.37 \times 10^{-6}$ ) for the whole set of data. This correlation was higher $(r=$ $0.211, P=1.37 \times 10^{-6}$ ) if only partially resistant plants were considered. So symptom score was the criterion chosen to classify plants as susceptible or partially resistant (see materials and methods). According to agronomic significance, data chosen to study the genetic control of the resistance were those recorded at $60 \mathrm{dpi}$.

The appearance of susceptible plants in L102 supports that the gene or genes controlling resistance must have incomplete penetrance. Moreover, the high percentage of susceptible plants in the $F_{1}$ indicated that resistance was not dominant. Thus, the proposed model needed to consider incomplete penetration and partial dominance of resistance. The observed percentages of partially resistant and susceptible plants for each generation were fitted to a monogenic model with two parameters to consider these effects (Table 3 ). The parameters, $p$ and $q$, indicated the probability of susceptibility for, respectively, a homozygous or heterozygous plant for the resistance gene. The parameters were estimated by weighted least square regression (Table 4). Both parameters were highly significant. The estimate for parameter $p$ indicates incomplete penetrance of resistance since approximately $27 \%$ of homozygous plants for the resistance gene are susceptible. The estimate for parameter $q$ exceeds $p$, thus indicating partial recessiveness. The fit of each generation to the model was confirmed by comparing the observed and expected values. Data from all generations together also fit the proposed model and thus explained the observed data.

Characterization of dominance of resistance to TYLCD derived from $S$. pimpinellifolium in different S. lycopersicum genetic backgrounds. Symptom development and viral accumulation were evaluated in hybrids among four breeding lines susceptible to TYLCD and L102. The response of the four hybrids was intermediate between resistant and susceptible controls. Symptom development was de- layed compared with the susceptible control (Table 1). The percentage of plants showing severe symptoms was lower than for FC, but in all cases, higher than for the resistant controls. Important differences were observed among the four hybrids, with the percentage of partially resistant plants at 45 dpi ranging from 10 to 47.1 . The most severe symptoms and lowest percentage of partially resistant plants appeared in the hybrid involving NE-1, followed by plants of P-73 $\times$ L102. Plants of the hybrid with FC showed a delay in symptom development with respect to plants of the other three hybrids; however, at the end of the assay, most of the plants of this hybrid behaved as susceptible. The best response among the four hybrids was exhibited by V-5-7 $\times$ L102, which at the end of the assay showed a percentage of partially resistant plants similar to that displayed by Pimhir.

Viral accumulation was also measured. Levels of virus detected increased along with dpi and the maximum was reached at 35 dpi. At this date, viral accumulation detected in the hybrids P-73 $\times$ L 102, FC $\times$ L102, and NE-1 $\times$ L102 did not significantly differ from that showed by the susceptible control FC (Fig. 1). However, the amount of virus accumulated in the hybrid

Table 2. Number of plants in each score of Tomato yellow leaf curl virus symptoms in the parents, $\mathrm{F}_{1}, \mathrm{~F}_{2}$, and $\mathrm{BC}$ generations from the cross Fortuna $\mathrm{C} \times \mathrm{L} 102$

\begin{tabular}{|c|c|c|c|c|c|c|c|c|c|c|c|c|}
\hline \multirow[b]{2}{*}{ Generation } & \multirow{2}{*}{$\begin{array}{c}\text { No. } \\
\text { plants }\end{array}$} & \multirow[b]{2}{*}{$\mathbf{d p i} \mathbf{i}^{\mathbf{b}}$} & \multicolumn{9}{|c|}{ No. of plants assigned score ${ }^{a}$} & \multirow{2}{*}{$\begin{array}{l}\text { Mean } \\
\text { score }\end{array}$} \\
\hline & & & $\mathbf{0}$ & 0.5 & 1 & 1.5 & 2 & 2.5 & 3 & 3.5 & 4 & \\
\hline \multirow[t]{5}{*}{ Fortuna $\mathrm{C}$} & 19 & 15 & 0 & 0 & 0 & 2 & 1 & 2 & 3 & 6 & 5 & 3.16 \\
\hline & & 25 & 0 & 0 & 0 & 0 & 0 & 0 & 0 & 0 & 19 & 4.00 \\
\hline & & 35 & 0 & 0 & 0 & 0 & 0 & 0 & 0 & 0 & 19 & 4.00 \\
\hline & & 45 & 0 & 0 & 0 & 0 & 0 & 0 & 0 & 0 & 19 & 4.00 \\
\hline & & 60 & 0 & 0 & 0 & 0 & 0 & 0 & 0 & 0 & 19 & 4.00 \\
\hline \multirow[t]{5}{*}{ L102 } & 15 & 15 & 9 & 2 & 3 & 1 & 0 & 0 & 0 & 0 & 0 & 0.37 \\
\hline & & 25 & 3 & 3 & 0 & 3 & 5 & 1 & 0 & 0 & 0 & 1.23 \\
\hline & & 35 & 0 & 1 & 6 & 3 & 5 & 0 & 0 & 0 & 0 & 1.40 \\
\hline & & 45 & 0 & 3 & 7 & 3 & 1 & 1 & 0 & 0 & 0 & 1.17 \\
\hline & & 60 & 0 & 2 & 6 & 3 & 3 & 1 & 0 & 0 & 0 & 1.33 \\
\hline \multirow[t]{5}{*}{$\mathrm{F}_{1}$} & 18 & 15 & 8 & 2 & 1 & 4 & 0 & 3 & 0 & 0 & 0 & 0.86 \\
\hline & & 25 & 2 & 1 & 7 & 3 & 3 & 0 & 2 & 0 & 0 & 1.33 \\
\hline & & 35 & 1 & 1 & 2 & 5 & 6 & 0 & 3 & 0 & 0 & 1.72 \\
\hline & & 45 & 0 & 1 & 3 & 0 & 5 & 9 & 0 & 0 & 0 & 2.00 \\
\hline & & 60 & 0 & 1 & 3 & 0 & 5 & 9 & 0 & 0 & 0 & 2.00 \\
\hline \multirow[t]{5}{*}{$\mathrm{F}_{2}$} & 124 & 15 & 34 & 14 & 25 & 6 & 13 & 19 & 8 & 2 & 3 & 1.27 \\
\hline & & 25 & 1 & 12 & 13 & 10 & 26 & 14 & 26 & 15 & 7 & 2.25 \\
\hline & & 35 & 1 & 3 & 11 & 4 & 22 & 35 & 31 & 11 & 6 & 2.46 \\
\hline & & 45 & 0 & 2 & 1 & 5 & 22 & 40 & 33 & 16 & 5 & 2.65 \\
\hline & & 60 & 0 & 2 & 1 & 5 & 23 & 37 & 35 & 16 & 5 & 2.65 \\
\hline \multirow[t]{5}{*}{$\mathrm{BC}_{1}$} & 96 & 15 & 14 & 6 & 10 & 13 & 10 & 15 & 18 & 4 & 6 & 1.90 \\
\hline & & 25 & 1 & 2 & 4 & 3 & 3 & 7 & 26 & 14 & 36 & 3.17 \\
\hline & & 35 & 1 & 0 & 6 & 3 & 4 & 8 & 28 & 23 & 23 & 3.07 \\
\hline & & 45 & 0 & 0 & 0 & 0 & 0 & 10 & 30 & 30 & 26 & 3.38 \\
\hline & & 60 & 0 & 0 & 0 & 0 & 0 & 10 & 30 & 30 & 26 & 3.38 \\
\hline \multirow[t]{5}{*}{$\mathrm{BC}_{2}$} & 84 & 15 & 31 & 14 & 19 & 7 & 11 & 2 & 0 & 0 & 0 & 0.76 \\
\hline & & 25 & 11 & 17 & 17 & 16 & 10 & 5 & 6 & 2 & 0 & 1.27 \\
\hline & & 35 & 3 & 14 & 20 & 11 & 22 & 12 & 2 & 0 & 0 & 1.47 \\
\hline & & 45 & 0 & 12 & 19 & 16 & 24 & 13 & 0 & 0 & 0 & 1.54 \\
\hline & & 60 & 0 & 9 & 14 & 15 & 38 & 8 & 0 & 0 & 0 & 1.63 \\
\hline
\end{tabular}

\footnotetext{
a Symptom score from 0 (symptomless) to 4 (severe symptoms). See text for further description of the scale.
}

$\mathrm{b}$ dpi = Days postinoculation. 
V-5-7 $\times$ L102 was similar to that in the partially resistant parent L102 and in the resistant Pimhir control.

There was a positive correlation $(r=$ $0.276, P=1.17 \times 10^{-6}$ ) between symptom development and viral accumulation for the four hybrids assayed.

\section{DISCUSSION}

Commercial materials resistant to TYLCD have been developed mainly on the basis of resistance derived from $S$. chilense and S. peruvianum. It is of interest to make use of the resistance found in other wild-tomato relatives. Variable levels of resistance have been found in different $S$. pimpinellifolium accessions, but currently, resistance derived from this source has not been exploited in developing commercial resistant materials. This study shows the usefulness of $S$. pimpinellifolium UPV16991 in breeding for resistance to TYLCD.

The response observed in the successive selfing generations from UPV16991 was homogeneous. Therefore, it could be assumed that the gene or genes controlling the partial resistance are fixed. The resistance derived from this accession was characterized by a restriction in viral accumulation and a delay in time of symptom development. However, at each selfing generation, a variable percentage of susceptible plants appeared, indicating the incomplete penetrance of the resistance.

The incomplete penetrance of resistance derived from $S$. pimpinellifolium seems to be the general pattern, as is also suggested by similar results found by other authors when studying different accessions of this species (13). Moreover, some authors have reported a complex genetics of the resistance derived from different $S$. pimpinellifolium accessions $(3,11,13,16)$. These two facts would explain that, to date, resistance derived from this wild species has not been exploited to develop commercial materials resistant to TYLCD. However, some studies revealed that combining resistance derived from other wild-tomato relatives with S. pimpinellifolium-derived resistance an increase in the level of resistance was obtained $(16,23,36)$. Thus, the resistance to TYLCD derived from $S$. pimpinellifolium could be useful if it was controlled by one or a few genes and expressed in S. lycopersicum background.

Inheritance studies were carried out that considered symptom development and viral accumulation for the six generations. There was a significant positive correlation between both parameters. Thus, the criteria ultimately established to classify each individual plant as susceptible or partially resistant were on the basis of symptom

Table 3. Monogenic model proposed to explain the inheritance of tomato yellow leaf curl disease (TYLCD) resistance derived from Solanum pimpinellifolium UPV16991. Incomplete penetrance and partial recessiveness are considered on the basis of the proportion of partially resistant and susceptible plants obtained in the studied generations

\begin{tabular}{lllcc}
\hline Generations & & Model & $\begin{array}{c}\text { Number of } \\
\text { plants observed }\end{array}$ & $\begin{array}{c}\text { Number of } \\
\text { plants predicted }^{\mathbf{a}}\end{array}$ \\
\hline $\mathrm{P}_{2}(\mathrm{~L} 102)$ & $\mathrm{S}^{\mathrm{b}}$ & $p^{\mathrm{c}}$ & 4 & 4 \\
$\mathrm{~F}_{1}(\mathrm{FC} \times \mathrm{L} 102)$ & $\mathrm{R}^{\mathrm{d}}$ & $1-p$ & 11 & 11 \\
& $\mathrm{~S}$ & $q^{\mathrm{e}}$ & 14 & 18 \\
$\mathrm{~F}_{2}\left(\mathrm{selfed} \mathrm{F}_{1}\right)$ & $\mathrm{R}$ & $1-q$ & 4 & 0 \\
& $\mathrm{~S}$ & $0.25+0.25 p+0.5 q$ & 116 & 101 \\
$\mathrm{BC}_{1}\left(\mathrm{FC} \times \mathrm{F}_{1}\right)$ & $\mathrm{R}$ & $0.75-(0.25 p+0.5 q)$ & 8 & 23 \\
& $\mathrm{~S}$ & $0.5+0.5 q$ & 96 & 96 \\
$\mathrm{BC}_{2}\left(\mathrm{~L} 102 \times \mathrm{F}_{1}\right)$ & $\mathrm{R}$ & $0.5-0.5 q$ & 0 & 0 \\
& $\mathrm{~S}$ & $0.5 p+0.5 q$ & 46 & 53 \\
& $\mathrm{R}$ & $1-(0.5 p+0.5 q)$ & 38 & 31 \\
\hline
\end{tabular}

${ }^{\text {a }}$ Prediction based on estimates for $p$ and $q$ by least square regression method.

b Susceptible plants.

${ }^{c}$ Probability of susceptibility of a homozygous plant for the resistance gene.

d Partially resistant plants.

${ }^{\mathrm{e}}$ Probability of susceptibility of a heterozygous plant for the resistance gene.

Table 4. Estimates by the least square regression method of the proportion of susceptible plants in homozygous $(p)$ and heterozygous $(q)$ for the resistance gene derived from Solanum pimpinellifolium UPV16991

\begin{tabular}{|c|c|c|}
\hline & $P$ & $q$ \\
\hline Estimate & 0.272 & 0.995 \\
\hline$P$ & 0.048 & 0.000 \\
\hline Standard error & 0.117 & 0.080 \\
\hline Confidence intervals $(95 \%)$ & $0.002-0.543$ & $0.810-1.179$ \\
\hline$R$-squared (adjusted for degrees of freedom) & \multicolumn{2}{|c|}{97.27} \\
\hline$\chi^{2}$ weighted & \multicolumn{2}{|c|}{3.255} \\
\hline$P$ & \multicolumn{2}{|c|}{0.354} \\
\hline
\end{tabular}
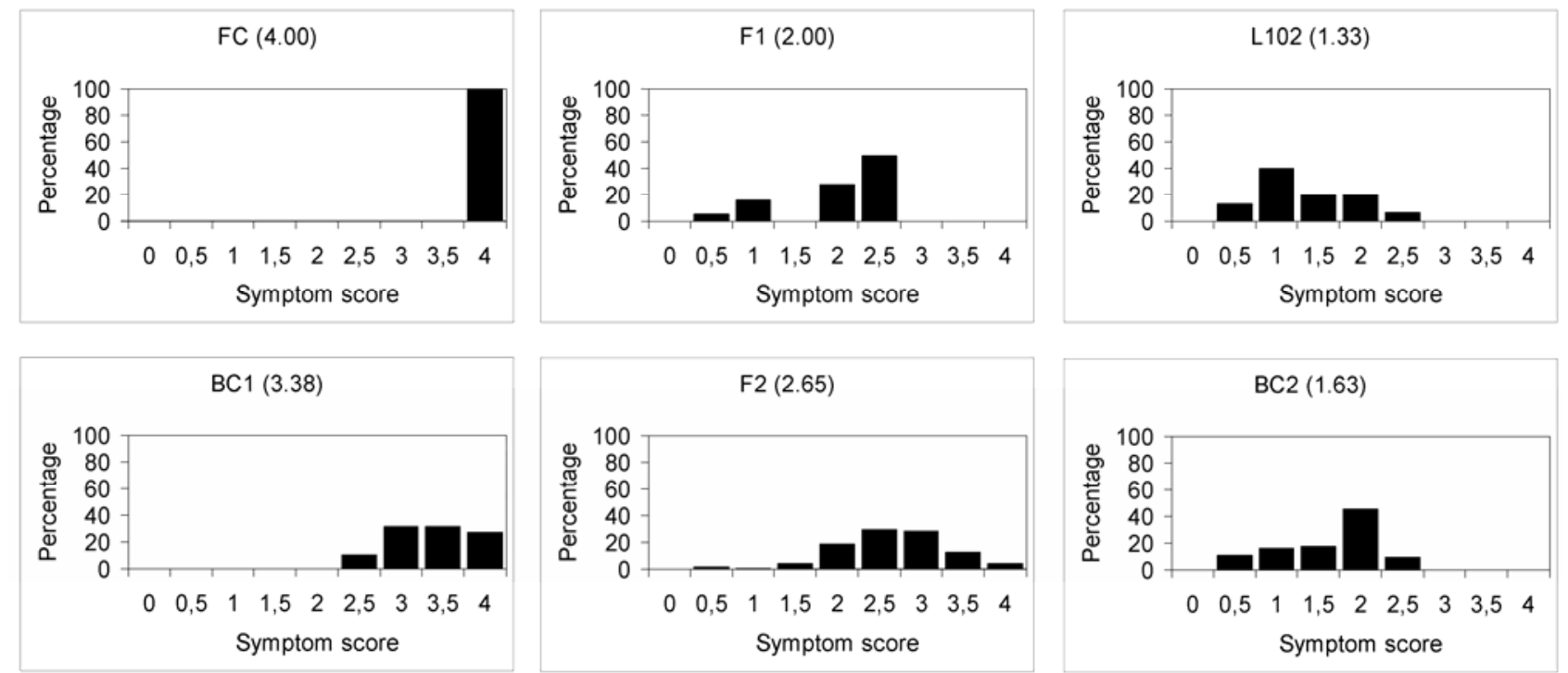

Fig. 2. Distribution of Tomato yellow leaf curl virus disease ratio 60 days postinoculation for $\mathrm{P}_{1}, \mathrm{P}_{2}, \mathrm{~F}_{1}, \mathrm{~F}_{2}, \mathrm{BC}_{1}$, and $\mathrm{BC}_{2}$ generations from the cross $\mathrm{FC} \times$ L102. Mean score for each generation is indicated in brackets. 
score at the end of the assay. In fact, most of the inheritance studies developed by different authors for resistance to TYLCD also used criteria based on symptom development. However, in most cases, plants were considered resistant only if they remained symptomless throughout the assay period $(12,13,15,19,31)$. Our criteria considered that a plant was partially resistant if it was either symptomless or showed only slight symptoms that would not cause yield losses. Kasrawi and Mansour (16) established similar criteria in their study of the genetics of resistance to TYLCV derived from $S$. pimpinellifolium HirsuteINRA where plants rated 0 were considered resistant, plants rated 4 were classified as susceptible, and plants in the remaining scores were considered to show variable levels of resistance. Other authors have established similar criteria when studying inheritance of resistance to different viral diseases such as Tomato leaf curl virus (ToLCV; 7), Cucumber mosaic virus (CMV; 32) or Tomato chlorotic mottle virus (ToCMoV; 8). These criteria turn out to be more useful in breeding programs, given that, as previously stated by Lapidot and Friedmann (17), the most relevant factor in evaluation for resistance is the effect of infection on total yield and yield components, but tests to compare yield in infected and noninfected plants can only be carried out for advanced materials of breeding programs.

It was under these premises that the results for the six generations were analyzed. The distribution of plants for each generation according to their symptom score suggested that the gene(s) controlling resistance had incomplete penetrance and partial dominance. Similar distributions were obtained by Kasrawi and Mansour (16) in families with S. pimpinellifoliumderived resistance and they inferred that the resistance was quantitatively inherited. The same conclusion was obtained from a very similar distribution when evaluating resistance to another geminivirus, Tomato mottle virus (ToMoV), derived from LA1932 (9). However, our data fit a monogenic model including partial recessiveness and incomplete penetrance. These results have implications for breeding purposes. Monogenic control of resistance facilitates introgression into the cultivated species. However, others have proposed a monogenic control of TYLCD resistance for other $S$. pimpinellifolium accessions that have not been used to develop commercial materials $(15,36)$. On the other hand, the effects of partial recessiveness and incomplete penetrance must be considered. In fact, given the high dependence of resistance on gene dosage (measured by parameter q), UPV16991-derived resistance should not be used in heterozygosis. As a consequence of incomplete penetrance, a percentage of homozygous plants for the resistance gene will be susceptible to the disease. However, symptoms developed by the susceptible plants of the resistance source were only moderate, even under the high inoculum pressure reached in this assay. Thus, in natural field conditions, a better response would be expected for homozygous plants. Currently, even recessive genes are useful in breeding programs, given that it is possible to develop molecular markers tightly linked to the gene of interest. This prospect would make introgression programs much easier and allow incorporating the resistance gene in both parental lines of hybrids.

The results obtained here suggest that the expression of resistance derived from $S$. pimpinellifolium UPV16991 strongly depends on the $S$. lycopersicum genetic background in which it is introgressed. The percentage of partially resistant plants ranged from 10.0 to 47.1 among the four hybrids assayed. The lowest percentage of susceptible plants and lowest levels of viral accumulation were detected in the hybrid V-5-7 $\times$ L102. This hybrid also showed the mildest symptoms. The V-5-7 line is the most vigorous of the four tomato lines used to develop the hybrids. This fact could explain the better response found in the cross involving this line. Similar results were found when studying lines derived from crosses between susceptible tomato cultivars and $S$. pimpinellifolium LA121 and LA373 where generations developed from the most vigorous materials showed less severe symptoms (25). The influence of the genetic background in the expression of resistance to TYLCD has also been reported for S. chilense (28) and S. habrochaites-derived resistance (23).

The influence of the genetic background on the expression of resistance derived from $S$. pimpinellifolium UPV16991 conditions its use in breeding programs. Parental lines must be selected by taking into account not only the heterosis of the hybrid but also the level of expression of the resistance.

In conclusion, we recommend the use of the resistance gene introgressed from UPV16991 in homozygosis in the development of vigorous hybrids. Another approach would be the combination of resistance reported here with resistance derived from different sources in an attempt to achieve a more durable resistance and increase its level.

\section{LITERATURE CITED}

1. Accotto, G. P., Bragaloni, M., Luison, D., Davino, S., and Davino, M. 2003. First report of tomato yellow leaf curl virus (TYLCV) in Italy. Plant Pathol. 52:799.

2. Antignus, Y., Lapidot, M., Hadar, D., Messika, Y., and Cohen, S. 1998. Ultraviolet-absorbing screens serve as optical barriers to protect crops from virus and insect pests. J. Econ. Entomol. 91:1401-1405.

3. Chagué, V., Mercier, J. C., Guenard, M., de Courcel, A., and Vedel, F. 1997. Identification of RAPD markers linked to a locus involved in quantitative resistance to TYLCV in tomato by bulked segregant analysis. Theor. Appl. Genet. 95:671-677.

4. Crespi, S., Accotto, G. P., Caciagli, P., and Gronenborn, B. 1991. Use of digoxigeninlabelled probes for detection and host-range studies of tomato yellow leaf curl geminivirus. Res. Virol. 142:283-288.

5. Fauquet, C. M., and Stanley, J. 2005. Revising the way we conceive and name viruses below the species level: A review of geminivirus taxonomy calls for new standardized isolate descriptors. Arch. Virol. 150:2151-2179.

6. Friedmann, M., Lapidot, M., Cohen, S., and Pilowsky, M. 1998. A novel source of resistance to tomato yellow leaf curl virus exhibiting a symptomless reaction to viral infection. J. Am. Soc. Hortic. Sci. 123:1004-1007.

7. Geneif, A. A. 1984. Breeding for resistance to tomato leaf curl virus in tomatoes in the $\mathrm{Su}$ dan. Acta Hortic. 143:469-484.

8. Giordano, L. B., Silva-Lobo, V. L., Santana, F. M., Fonseca, M. E. N., and Boiteux, L. S 2005. Inheritance of resistance to the bipartite Tomato chlorotic mottle begomovirus derived from Lycopersicon esculentum cv. 'Tyking'. Euphytica 143:27-33.

9. Griffiths, P. D., and Scott, J. W. 2001. Inheritance and linkage of Tomato mottle virus resistance genes derived from Lycopersicon chilense accession LA1932. J. Am. Soc. Hortic. Sci. 126: 462-467.

10. Hanson, P. M., Bernacchi, D., Green, S., Tanksley, S. D., Muniyappa, V., Padmaja, A. S., Chen, H., Kuo, G., Fang, D., and Chen, J. 2000. Mapping a wild tomato introgression associated with Tomato yellow leaf curl virus resistance in a cultivated tomato line. J. Am. Soc. Hortic. Sci. 125:15-20.

11. Hassan, A. A., and Abdel-Ati, K. E. A. 1999. Genetics of Tomato yellow leaf curl virus tolerante derived from Lycopersicon pimpinellifolium and Lycopersicon pennellii. Egypt. J. Hortic. 26:323-338.

12. Hassan, A. A., Mazayd, H. M., Moustafa, S. E., Nassar, S. H., Nakhla, M. K., and Sims, W. L. 1984. Inheritance of resistance to Tomato yellow leaf curl virus derived from Lycopersicon cheesmannii and Lycopersicon hirsutum. Hortic. Sci. 19:574-575

13. Hassan, A. A., Mazayd, H. M., Moustafa, S. E., Nassar, S. H., Nakhla, M. K., and Sims, W. L. 1984. Genetics and heritability of Tomato yellow leaf curl virus tolerance derived from Lycopersicon pimpinellifolium. European Association for Research on Plant Breeding. Tomato Working Group. Wageningen, Netherlands, pp. 81-87.

14. Holt, J., Colvin, J., and Muniyappa, V. 1999. Identifying control strategies for tomato leaf curl virus disease using an epidemiological model. J. Appl. Ecol. 36:625-633.

15. Kasrawi, M. A. 1989. Inheritance of resistance to Tomato yellow leaf curl virus (TYLCV) in Lycopersicon pimpinellifolium. Plant Dis. 73:435-437.

16. Kasrawi, M. A., and Mansour, A. 1994. Genetics of resistance to Tomato yellow leaf curl virus in tomato. J. Hortic. Sci. 69:1095-1100.

17. Lapidot, M., and Friedmann, M. 2002. Breeding for resistance to whitefly-transmitted geminiviruses. Ann. Appl. Biol. 140:109-127.

18. Lapidot, M., Friedmann, M., Lachman, O., Yehezkel, A., Nahom, S., Cohen, S., and Pilowsky, M. 1997. Comparison of resistance level to Tomato yellow leaf curl virus among commercial cultivars and breeding lines. Plant Dis. 81:1425-1428.

19. Lapidot, M., Golray, O., Ben-Joseph, R., Cohen, S., Friedmann, M., Sholmo, A., Nahon, S., Chen, L., and Pilowsky, M. 2000. Breeding tomatoes for resistance to Tomato yellow leaf curl begomovirus. EPPO Bull. 30:317-321

20. Laterrot, H. 1992. Resistance genitors to tomato yellow leaf curl virus (TYLCV). Tomato 
Leaf Curl Newsl. 1:2-4.

21. Laterrot, H. 1995. Breeding network to create tomato varieties resistant to Tomato yellow leaf curl virus (TYLCV). Fruits 50:439-444.

22. Louro, D., Noris, E., Veratti, F., and Accotto, G. P. 1996. First report of tomato yellow leaf curl virus in Portugal. Plant Dis. 80:1079.

23. Mejia, L., Teni, R. E., Vidavsky, F., Czosnek, H., Lapidot, M., Nakhla, M. K., and Maxwell, D. P. 2005. Evaluation of tomato germplasm and selection of breeding lines for resistance to begomoviruses in Guatemala. Acta Hortic. 695:251-255

24. Moriones, E., and Navas-Castillo, J. 2000. Tomato yellow leaf curl virus, an emerging virus complex causing the epidemics worldwide. Virus Res. 71:123-134

25. Moustafa, S. E. S., and Nakhla, M. K. 1990. An attempt to develop a new tomato variety resistant to Tomato yellow leaf curl virus (TYLCV). Assiut J. Agric. Sci. 21:167-183.

26. Navas-Castillo, J., Sánchez-Campos, S., Díaz, J. A., Sáez-Alonso, E., and Moriones, E. 1997. First report of tomato yellow leaf curl virus-Is in Spain: Coexistence of two different geminiviruses in the same epidemic outbreak. Plant Dis. 81:1461.

27. Picó, B., Díez, M. J., and Nuez, F. 1996. Viral diseases causing the greatest economic losses to the tomato crop. II. The Tomato yellow leaf curl virus - a review. Sci. Hortic. 67:151-196.

28. Picó, B., Ferriol, M., Díez, M. J., and Nuez, F. 1999. Developing tomato breeding lines resistant to tomato yellow leaf curl virus. Plant Breed. 118:537-542.

29. Picó, B., Sifres, A., Elía, M., Díez, M. J., and Nuez, F. 2000. Searching for new resistance sources to tomato yellow leaf curl virus within a highly variable wild Lycopersicon genetic pool. Acta Physiol. Plant. 22:344-350.

30. Pilowsky, M., and Cohen, S. 1974. Inheritance of resistance to Tomato yellow leaf curl virus in tomatoes. Phytopathology 64:632-635.

31. Pilowsky, M., and Cohen, S. 1990. Tolerance to Tomato yellow leaf curl virus derived from Lycopersicon peruvianum. Plant Dis. 74:248250.

32. Stamova, B. S., and Chetelat, R. T. 2000. Inheritance and genetic mapping of cucumber mosaic virus resistance introgressed from $L y$ copersicon chilense into tomato. Theor. Appl. Genet. 101:527-537.

33. Stansly, P. A., Sánchez, P. A., Rodríguez, J. M., Cañizares, F., Nieto, A., López-Leyva, M. J., Fajardo, M., Suarez, V., and Urbaneja, A. 2004. Prospects for biological control of $\mathrm{Be}$ - misia tabaci (Homoptera, Aleyrodidae) in greenhouse tomatoes of southern Spain. Crop Prot. 23:701-712.

34. Velasco, L., Morales, M. A., Catalá, M. S., and Costa, J. 2005. El empleo de mallas fotoselectivas para reducir la incidencia de TYLCD en el cultivo: influencia del fondo genético varietal. Actas Port. Hortic. 7:224-227.

35. Vidavsky, F., and Czosnek, H. 1998. Tomato breeding lines resistant and tolerant to Tomato yellow leaf curl virus issued from Lycopersi con hirsutum. Phytopathology 88:910-914.

36. Vidavsky, F., Leviatov, S., Milo, J., Rabinowitch, H. D., Kedar, N., and Czosnek, H. 1998. Response of tolerant breeding lines of tomato, Lycopersicon esculentum, originating from three different sources $(L$ peruvianum, $L$. pimpinellifolium and $L$. chilense) to early controlled inoculation by Tomato yellow leaf curl virus (TYLCV). Plant Breed. 117:165-167.

37. Zamir, D., Michelson, I. E., Zakay, Y., Navot, N., Zeidan, M., Sarfatti, M., Eshed, Y., Harel, E., Pleban, T., van Oss, H., Kedar, N. Rabinowitch, H. D., and Czosnek, H. 1994 Mapping and introgression of a Tomato yellow leaf curl virus tolerance gene, $T y-1$. Theor. Appl. Genet. 88:141-146. 